\title{
THE LEADERSHIP OF EDUCATION RESEARCHERS IN LITHUANIAN UNIVERSITIES
}

\author{
Dalia Survutaitè \\ Vytautas Magnus University Education Academy, Lithuania
}

\begin{abstract}
The article gives overview and analyses the changes and development of scientific research on educational sciences in Lithuanian universities in the period of 1990-2004. The prepared and successfully defended dissertations show positioning of the research field of educational sciences: the leadership of education researchers is reflected by the diplomas of habilitated doctors and certificates of pedagogical title of professor. The statistical overview and evaluation of doctoral dissertations in the research field of educational sciences (social sciences) in the period of 1990-2004 reveal that training of education researchers occurred both in separate universities and in the networks of universities. The distribution of researchers in Lithuanian higher education is also discussed. The statistical data on habilitated doctors in social sciences and doctoral dissertations in education defended in the period of 1990-2004 illustrate the need to develop researchers of highest qualification in Lithuanian universities. The case study of Lithuanian University of Educational Sciences allows revealing the leadership of education researchers in training of doctoral students.
\end{abstract}

Keywords: university, educational science, researchers, dissertation, leadership.

\section{Introduction}

After the restoration of independence in Lithuania in 1990 education was seen as the most important factor of society's modernisation. Well-educated society ensures high quality of life and efficiently responds to the global changes of contemporary world. Therefore, higher education marks the priority of society for quality education. Phenomena of changing society predetermined need for intensive research in the field of social sciences and particularly in education and training of education researchers. It was important for the inner development of Lithuania and for preparation to integrate into EU. "Developing European culture and creating a single European higher education area, a particular attention is allocated to such institutions as universities” (Laurutis, Gumuliauskienè, 2003, p. 207). Following the Lithuanian Qualification Framework, the qualification of the doctor of science is assigned to the highest Level 8 (Resolution of the Government of RL, 24 August 2011). The requirements for qualification of this level are in line with the criteria of the European Union.

The article analyses the contribution of separate Lithuanian higher-education institutions to training of education researchers and their role as leaders in 
educational science. Employing theories of leadership, the role of researchers in education of doctoral students is analysed. Up to now the theory of leadership has been linked to interaction between the andragogue and learners (Adomaitiené, Zubrickienè, 2012, p. 10-24.). Over the recent years, the role of the principal as a transformational leader in the process of school change and manifestations of teacher's transformational leadership (Leithwood, Jantzi, 1990; Leithwood, Jantzi, 1999; Navickaitè, Janiūnaitè, 2012; Anderson, 2008) have been analysed. Though the majority of research studies (MacBeath, Myers, 1999; Martinez, 2004; Leithwood, Jantzi, 2006; Rupšienè, Skarbalienè, 2010; Kelley, 2011; Bujokaitė [Ratkevičienè], 2013) focused on the teacher's leadership, the expression of leadership of researchers in higher-education institutions has not been analysed in a substantive way. Acknowledging a considerable contribution of researchers to "training of doctors in education, discussions of methodological approaches, highlighting the relation between the object and the method, opening new research areas” (Teresevičienè, 2012, p. 55), it is important to evaluate the leadership of education researchers. The leadership of education researchers is a critical dimension (Santos, Horta, 2018) in the creation of knowledge since it represents the starting point of a process that embeds individual researchers' (and the communities that they identify themselves with) interest for shedding light on topical unknowns, intrinsic and extrinsic factors underpinning that motivation, and the ambition and scope of what a research endeavor can bring.

The leadership of education researchers has to be investigated for several reasons. Firstly, this allows evaluating contribution to education of researchers in educational science, discussion of methodological approaches and opening of new research areas. Secondly, this expands the limits of cognition of educational phenomena, enables essential understanding of the current situation of the educational sciences and factors predetermining the quality of educational reality. Leadership of education researchers creates prerequisites for forecasting the perspectives of development of educational sciences in universities. The most important role in education research is assigned to universities. Evaluating the situation of education and training, education research carried out in Lithuanian universities as well as young researchers educated by experienced ones play a significant role.

The research object: the leadership of researchers in the research field of educational sciences.

The goal: to investigate the leadership of education researchers in Lithuanian universities.

\section{The objectives:}

To characterise training of education researchers in Lithuanian higher education.

To highlight spread of education researchers in Lithuanian universities. 
To illustrate expression of leadership of education researchers analysing establishers of the tradition of educational sciences in Lithuanian University of Educational Sciences.

The logic sequence of the article consists of characterisation of training of education researchers in Lithuanian universities, highlighting the spread of education researchers in universities, expression of leadership of education researchers through the case study of one university.

Theoretical research is based on the provisions of transformational leadership emphasising the transformational influence on the followers and encouraging them to pursue higher goals (Bass, 2008; Northouse, 2009). Implementing their activity goals, the leaders in educational sciences not only completed necessary organisational assignments but also motivated their followers for new research. Relation-oriented leadership is people focused, inspirational, persuasive, and intellectually stimulating (Bass, 2008). The transformational leader convinced his followers to transcend their self-interest for the sake of the organization, while elevating "the followers' level of need on Maslow's (1954) hierarchy from lowerlevel concerns for safety and security to higher-level needs for achievement and self-actualization” (Bass, 2008, p. 619). In this context the leadership of education researchers is revealed as an essential potential of the research field of educational sciences (social sciences) with the power to influence the reality of education and to implement separate directions in educational changes aiming at sustainability of education and education progress.

The data for the article were collected employing theoretical research methods - mainly analysis of scholarly literature and educational documents, analysis and generalisation of archival documents of one university. Seeking to completely substantiate the analysed object, the quantitative method of secondary data analysis was used. Analysing the habilitation and doctoral dissertations registered in the period of 1990-2004, the spread of education researchers in Lithuanian universities was investigated.

The set of the data analysed in the article embraced 208 doctors in educational sciences (social sciences - according to the approved classification of sciences, social sciences (S000) make up one of the branches of sciences. Educational sciences $(07 \mathrm{~S}$ ) are among its eight areas), and also groups of researchers, who defended dissertations in educational science in Vilnius Pedagogical University (VPU) (later - Lithuanian University of Educational Sciences, LEU) in the period of 1993-2004: a) candidates of pedagogy with diplomas of doctors of science nostrified in Lithuania, b) doctors in educational sciences by 2004; c) holders of diplomas of habilitated doctors by 2004; d) holders of certificates of the professor's pedagogical title. 


\section{Consolidation of Educational Sciences and Training of Education Researchers in Lithuania}

At the end of the 20th century, educational science underwent considerable qualitative changes in Lithuania. Various educational phenomena, such as education, self-education, pedagogy, andragogy, upbringing, training, teaching, learning and others, were intensively analysed. The broader term "educational science" (educology) replaced the term "pedagogy". The conception about the educational sciences as an integrated science investigating education and selfeducation of an individual, all his/her life both from the perspective of direct education process and from that of education as a complex phenomenon with educational systems realising it was established (Jucevičienè, 1997). The educational sciences have acquired aspects of fundamentality, its essential methodological characteristics have been formulated, and institutional nature of education has undergone changes. A more universal conception of the object of educational sciences, which integrates issues of management of education, educational policy, educational sociology and economics and others in an interdisciplinary way, is characteristic of this modern paradigm. The role of the nucleus is ascribed to educational sciences in the modern paradigm (Mialeret, 1985; Jucevičienè, 1997).

Prior to the restoration of the independence of Lithuania a big number of researchers worked in the Institute of Scientific Research on Pedagogy, where currently prominent Lithuanian researchers on pedagogy - professors, habilitated doctors B. Bitinas, L. Jovaiša, A. Katinienè, V. Rajeckas, V. Šernas, J. Uzdila, J. Vaitkevičius, M. Barkauskaitè worked next to Dr. J. Laužikas and Dr. M. Lukšienè. Thus, the activities of the Institute of Scientific Research on Pedagogy intensified scientific research in pedagogy, enhanced maturity of staff's research qualification and their leadership. Improving research qualification revealed the tendency of specialists' going to other higher education institutions (Movement of researchers from Institute of Scientific Research on Pedagogy to oher institutions: to VSPI (Z. Pilkauskas), to ŠPI (B. Bitinas), to VSU (L. Jovaiša, later A. Šoblinskas, V. Aramavičiūtè), to VGTU (V. Šernas, M. Gylienè, L. Vaitkūnienė, V. Treigienė), to VSPI (a whole squad, indeed: S. Vyšniauskas, M. Barkauskaitè, S. Jankevičius, R. Kontvainas, V. Glebuvienė, J. Galkauskas, J. Unčiurys, J. Uzdila, J. Žilionis, A. Vilkas, etc.). The majority of them were appointed to the posts of heads of dean's offices or other divisions. Using the experience acquired in the Institute, they accumulated research results and created methodologies, some of them wrote and defended their habilitation dissertations and became professors, and significantly contributed to the development of science of pedagogy (Dobrovolskis, 2009, p. 197). The scientific researchers, who started work in the Institute of Scientific Research on Pedagogy, spread to higher education institutions to continue their 
research and teaching activities. Vilnius State University (VSU), Vilnius State Pedagogical Institute (VSPI) and Šiauliai Pedagogical Institute (ŠPI) became the centres of gravity for the science of education. After the restoration of independence of Lithuania on the 11th March 1990, reforms of teaching and administrative work in higher education schools were implemented and some institutions underwent reorganisation and changed their names.

The reforms in training of education researchers in the period of 1990-2004 can be divided into separate stages linking them with the decades in the development of the independent state. The first period (1990-1992) is related to consolidation of the science of pedagogy at the university and to the preservation of unique and significant heritage of pedagogy. The object of the science of pedagogy was limited to issues regarding relation of the goal, educational means and educational outcomes of children education (from infantry to adulthood) (Karčiauskienė, Vaitkevičius, Bitinas, Rajeckas, 1993). At that period the purpose of traditional pedagogy was to directly analyse interaction of and in education. The second period (1992- 2003) is related to the legally assigned right to grant the doctor's degree in research and study institutions (Resolution of the Government of RL, No. 739, 9 October 1992). At that period training of education researchers was organised both in separate universities and university networks. The distinguished periods illustrate the developmental tendencies of the pedagogy science in Lithuanian universities and potential trends of expression and development of leadership of education researchers.

\section{Disposition of the Field of Educational Science and Leadership of Universities}

After the restoration of independence, the Commission of Nostrification of Research Degrees and Titles formed under the Research Council of Lithuania reviewed and evaluated all the dissertations defended during the soviet period. Conducting teaching activities and developing their research, the researchers defended their habilitation works in several Lithuanian universities. During the analysed period the majority of defended habilitation dissertations were prepared by researchers from Vilnius Pedagogical University (previously - Vilnius State Pedagogical Institute) together with those from Šiauliai University (previously Šiauliai Pedagogical Institute) (see: Fig. 1).

From 1983 to 1992146 dissertations were defended all in all and 15 of them were defended to obtain the degree of doctor habilitatus. The geography of pedagogical researchers prepared during the first decade of independence is rather broad. The biggest number of dissertations were written and defenced by specialists in Vilnius Pedagogical University: 8 dissertations for the degree of habilitated doctors and 9 doctoral dissertations. Having investigated the topics and content of the dissertations defended by 1992, Voverienè (1995) made a conclusion that only $3.6 \%$ of the dissertations defended in pedagogy aimed at propagation of ideology 
of the Communist party, at ideological and atheistic education of school children (Voverienè, 1995).

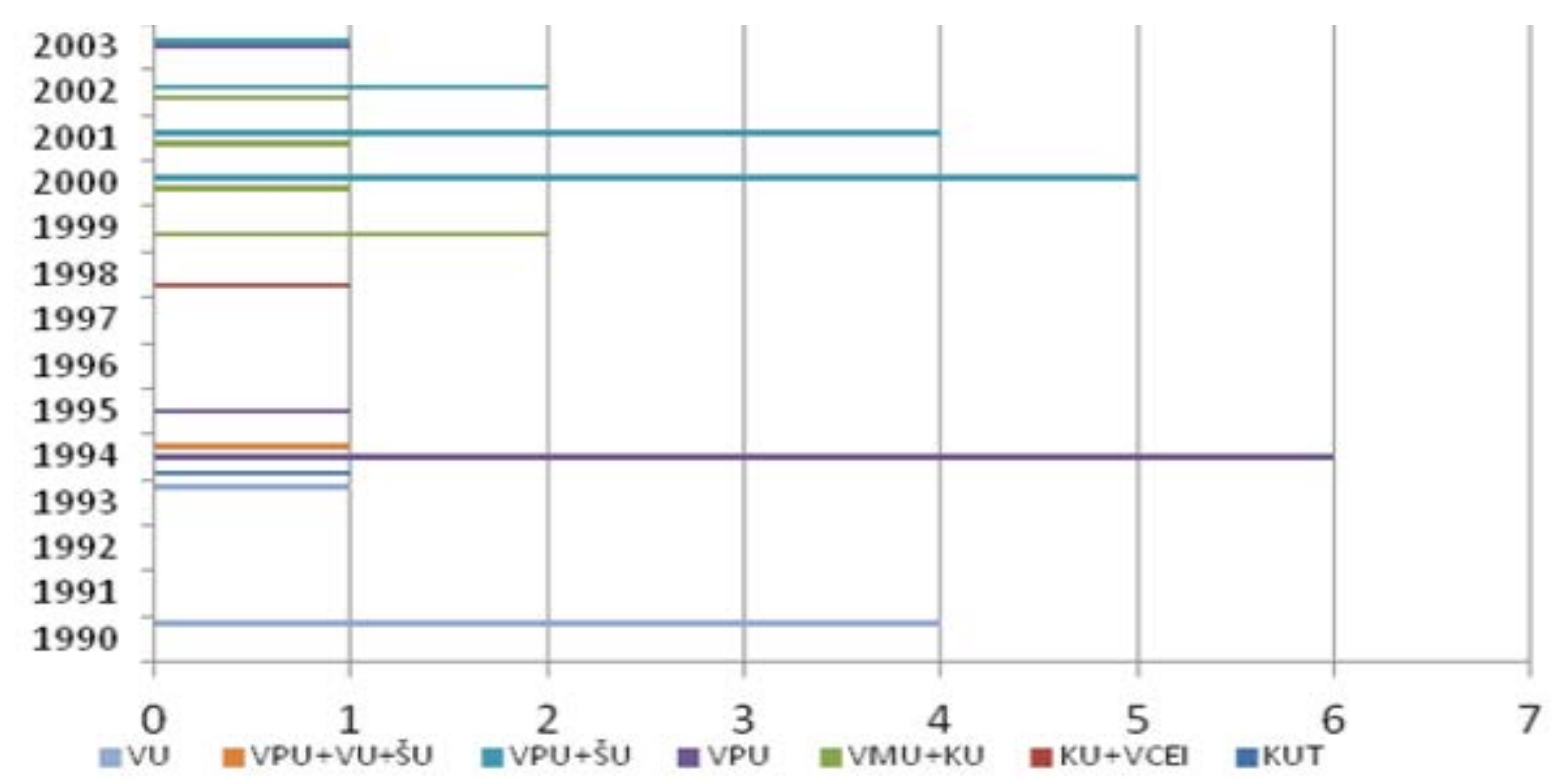

Figure 1 Recognition of the Diplomas of Habilitated Doctors in the Period of 1990-2003

In the period of 1993-1995 P. Šapokienè P. Karoblis, B. Bitinas, V. Rajeckas and M. Karčiauskienè were the first to be conferred the diplomas of habilitated doctors. Seeing numerous problems occurring in educational activities and the system of education in general, such researchers as B. Bitinas, V. Rajeckas and M. Barkauskaite initiated targeted activities towards increasing the number of education researchers. V. Rajeckas states that during the first decade of the independence more than 130 doctors of science were prepared (Rajeckas, 1999). The total number of dissertations in pedagogy, which were defended in Lithuania, exceeded the numbers in the other Baltic countries, i.e. in Estonia and Latvia taken together, as well as in Belarus. The number of habilitated doctors in pedagogy in Lithuania reached the level of such a big nation as Ukraine.

Evaluating the topics of written dissertations, it can be stated that the dissertations elaborated on the issues of all the elements of the (Lithuanian) school system and some aspects of Western democracy, philosophy. Distinguishing common features of dissertations in pedagogy, it can be concluded that the majority of dissertations were research works of experimental character, which analysed practical activities of school, teacher and schoolchildren relations, and results of school performance (Vaitkevičius, 1992). The research in dissertations targeted at European democracy and followed philosophical pluralism prevailing in the Western world. 
In 2010 the Research Council of Lithuania published the digest of dissertations defended in the national universities (Lietuvos mokslo potencialas). The alphabetic list of researchers' names in educational sciences (07 S), social sciences, consisted of 709 researchers. It should be pointed out that in the period of 1995-1998 doctoral dissertations in educational science were defended in several higher education schools: in Klaipeda University (in 1995), in Kaunas University of Technology (1996, 1997), Vilnius Pedagogical University and Šiauliai University (1998). Since 2000 dissertations have been defended in all Lithuanian universities.

The data presented in Figures 1 and 2 show that VU, VMU, KUT, KU played a significant role in the research field of education. That statistical data show that from 1993 to 2004134 diplomas of doctor in educational science were granted in Lithuanian universities (out of them 33 dissertations, 24.5\%, were defended in LEU).

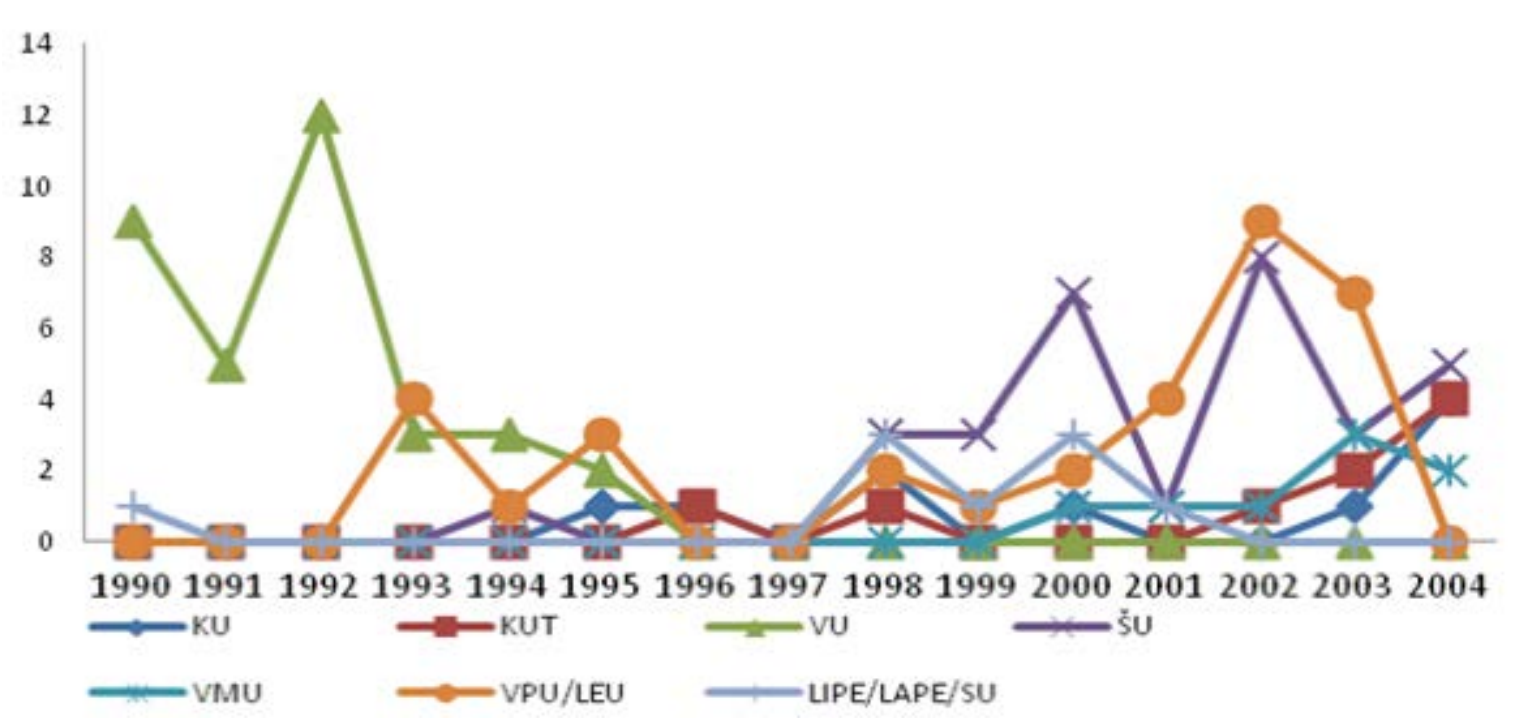

Figure 2 Defence of Doctoral Dissertations in Separate Universities in the Period of 1990-2004

Since 1996 the possibility of developing educational science has been handed to the consortium of universities. It has resulted in joint doctoral studies in such networks as: Vilnius Pedagogical University, Vilnius University, Šiauliai University; Vytautas Magnus University and Klaipèda University; Kaunas University of Technology and Vilnius University (see: Fig. 3). 


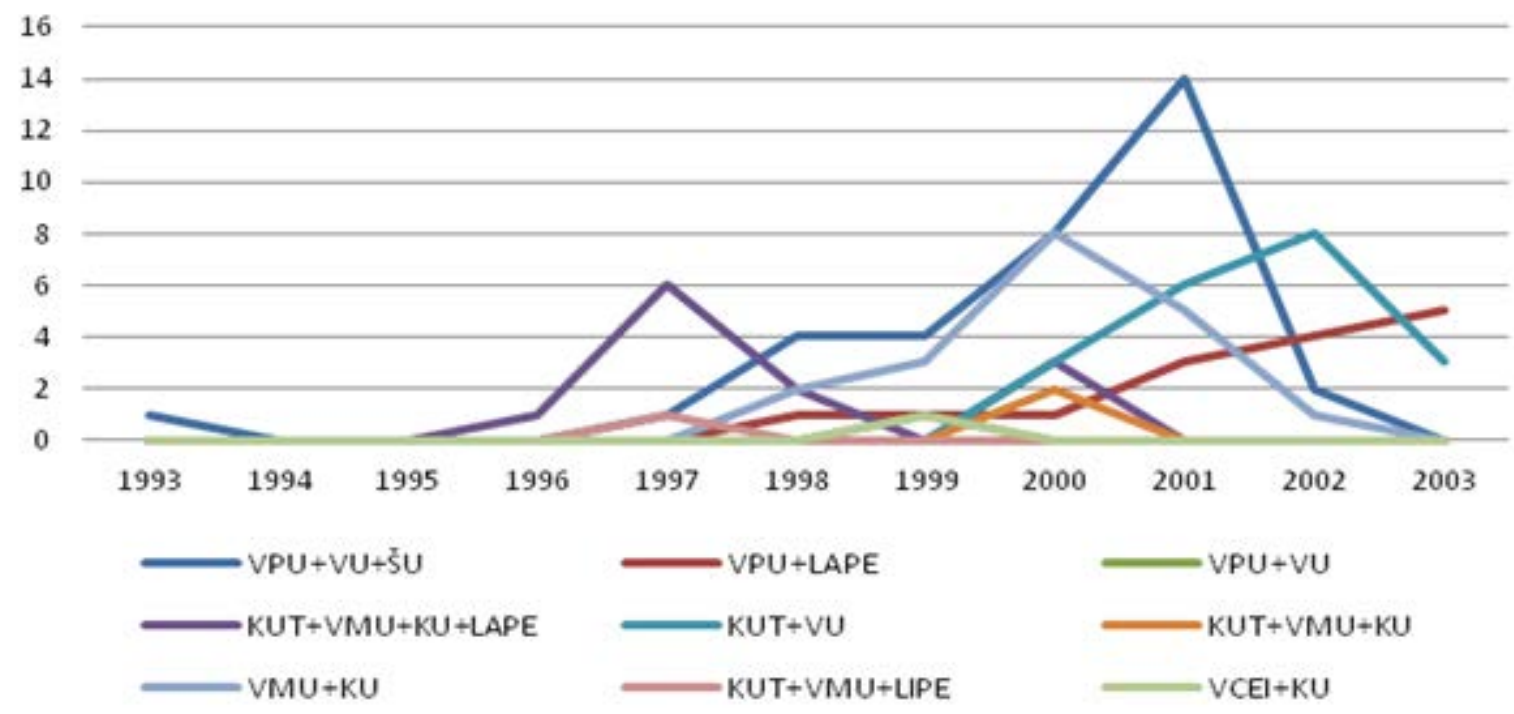

Figure 3 Preparation of Researchers in the Joint Doctoral Study Programme in Educational Science in the Period of 1993-2003

The disclosed data on doctoral dissertations defended in Lithuanian universities confirm that the basis of education researchers consists of the ones, who defended their doctoral dissertations after the restoration of independence. There emerged a possibility of initiating change and development of pedagogical and research potential, which, in its turn, would influence the quality of the whole system of education. The doctoral studies in the educational sciences (social sciences) encouraged development of teachers' educational, social, managerial and other competences. The doctoral studies in the universities established conditions for acquisition of broader, more modern and up to date educational, social, humanities and cultural education. The last decade of the 20th century was almost unique in the transformations of old educational conceptions and development of new ones. Participating in joint projects of national universities or international research, doctoral students acquired broader competences and possibilities in educational reforms, contributed to scientific, social and cultural development of Lithuania. Having defended their dissertations, doctors of educational sciences entered institutions of educational policy making and engaged into activities of research centres improving the quality of provided consultations and solving integral educational problems. Conducting new research education researchers expanded the educational sciences by new theories and changed the reality of education. Nurturing the national area of higher education, education researchers created a unified culture of education and self-education. Undergoing training doctoral students had extraordinary possibilities of continuing own professional career in different Lithuanian higher education schools. Lithuania's integration into the area of EU higher education led to investigation of such educational areas as the 
quality, accessibility of education, curriculum, openness and efficiency (The Concrete Future Objectives of Education Systems, 2001). It should be emphasised that revealing their leadership abilities highly qualified teachers demonstrated their determination and power to improve the quality of education.

Increasing numbers of students in universities resulted in enhancement of teachers' qualification. In some cases a half and sometimes a third of teaching staff members consisted of holders of doctoral degree or doctor habilitatus (Švietimas, 2001). Having defended their dissertations, employees of universities really took the leaders' positions.

\section{The Growth of Education Researchers}

The preparation and defense of doctoral dissertations were preconditioned by the links of universities with the particular subsystems of education, the specialists to which a higher education institution trained. The universities with pedagogical profile trained doctors, who analysed problems of primary, basic and secondary and higher-education institutions in their dissertations but at the same time focused more on creation, consolidation and substantiation of new teaching methods and methodologies (Barkauskaite, Martišauskienè, Česnavičienè, 2006, p. 10-17).

The period of leadership of education researchers in 1992-2003 was marked by the publicly announced Conception of Lithuanian Education (1992). Approaching retrospectively the cultural and social reform of education, the valuebased and paradigmatic transformation, i.e. transition from the classical to liberal education, is highlighted. According to Ž. Jackūnas (2006), the Lithuanian National Revival Movement (Sajūdis), which started in the year of "perestroika", gave birth to aspirations for educational reform based on need of freedom and democracy. After the restoration of Lithuanian independence, favourable conditions were established for providing an individual with education that responds to current needs and development of relevant abilities and moral foundations. By 1996 the proportion of dissertations defended in pedagogy made up $20 \%$ of the total number of dissertations. The dissertations prepared during that period were mainly of applied character and based on the data acquired during pedagogical experiments on experience of school activities. According to the research areas, the dissertations are distributed in the following way: the biggest number of dissertations were prepared on issues of didactics (18), physical education and sport (11), theory of upbringing (9), vocational guidance (8) and history of pedagogy (7) (Vaitkevičius, 1997, p. 336-339). More than forty research theses were prepared on issues of school-work.

Though this can be regarded as a rather significant contribution to the development of the science of pedagogy, the holistic aspect was not reflected in the dissertations on reforms of general education schools. Each defended dissertation 
addressed local issues of school activities not connecting them into systems, not embracing all the structural parts of the pedagogical process as an integral system; not considering opinions, needs, possibilities of schoolchildren's parents, society, teachers and even schoolchildren themselves as well as conditions for learning and teaching.

Fundamental research strengthened and the publishing of scientific educational journals significantly increased. The Catalogue of Scientific Journals (2011) presents scientific educational journals published in Lithuania: "Pedagogika" [Pedagogy] (Vilnius Pedagogical University), "Acta Paedagogica Vilnensia“ (Vilnius University), "Mokytojų ugdymas" [Teacher Education] (Šiauliai University) and others. The science of pedagogy was enriched with research on the history of Lithuanian school. A new area of pedagogical research, i.e. comparative educational science, appeared. Four dissertations, which analysed the systems of western countries (the USA, Switzerland, Denmark and France) were defended. At that period the most considerable attention was paid to research on problems of family and children's education in the family. "Education and training are analysed according to different levels and types of educational institutions (early childhood and pre-primary, primary, secondary education, higher education and studies), according to groups of different age (childhood pedagogy, adult education), according to peculiarities of population (special, social pedagogy, education of the gifted), according to educational paradigms (teaching and learning, liberal and social democratic education, etc.). Creativity, value education, learning strategies, efficiency of learning methods, subject-specific abilities and others are frequently chosen as the object of research" (Teresevičienè, 2012, p. 57).

Doctoral studies in pedagogy (educational science) were implemented in as many as seven higher education schools. The first inter-university network completing joint assignments and after evaluation of internationalisation of research, stated that emergence of international doctoral studies is inevitable (Rekomendacijos. Tarpuniversitetinès edukologijos doktorantūros sukūrimas, 2008, p. 181-182). It was decided to strengthen interuniversity cooperation and to improve the quality of doctoral dissertations emphasising originality, interpretations, conceptuality and methodological foundations of the research. The scientific supervisors in the universities decided to assign more attention to identification of exceptionality of educational sciences and to research on specifics of national research. The procedures for admission to doctoral studies changed and it was decided "to emphasise problems relevant to the strategy of policy on education and higher education as well as to consider the experience acquired by entrants and problems important in practice” (Teresevičienè, 2012, p. 58).

In the first decade of the 21st century Vilnius Pedagogical University remained the main teacher training institution in Lithuania. At the end of 1999 there were 52 doctoral students in the Faculty of Pedagogy and Psychology (Rajeckas, 1999). The 
following comparison can be provided: 1 habilitation dissertation and 5 doctoral dissertations were defended in Klaipeda University; 6 doctoral dissertations - in the Institute of Pedagogy; 3 habilitation and 1 doctoral dissertations - in Šiauliai Pedagogical Institute; 2 habilitation and 2 doctoral dissertations - in Vilnius University; 1 habilitation and 3 doctoral dissertations in Kaunas University of Technology. A number of trained researchers are teachers-practitioners, who have pursued their teaching careers. The choice of themes of dissertations was preconditioned by the relevant issues of the period. The dissertations defended in Klaipeda University analysed the problems of national education in the primary school in the period of 1918-1940 and moral education of children in rural community in the period of 1900-1940. Other dissertations aimed at analysis of educational issues: revelation of development of children's worldview in the Lithuanian primary school on the basis of educational programmes in 1918-1998; an analysis of pedagogical aspects of Catholic schools in Lithuania in the periods of 1918-1940 and 1991-2009, influence of national minorities on development of gymnasiums in Lithuania and on present secondary school. In the second period it was important to analyse the necessity of educational reform and its tendencies. Responding to global challenges of contemporary world, doctors in education committed to significant contribution to changes in own society. Lithuania's integration into the EU education area predetermined the following areas of research as "education quality, accessibility, curriculum reform, openness, efficiency" (The Concrete Future Objectives of Education Systems, 2001). Analysing the essence of the quality of education, a particular attention was paid to improvement of European learning standards and quality of teacher preparation. In such context more young researchers entered the area, whose training was organised in different Lithuanian universities.

Knowledge, information and ability to creatively apply them in the context of European educational dimensions have become social economic capital and a prerequisite for successful activity of an individual. In this context doctoral studies highlighted such general competences as critical thinking, efficient communication, group or team work, problem solving techniques, permanent learning, research skills and creativity. Teachers' activities in the society are becoming more and more visible and implementation of doctoral studies through shared leadership is influencing and changing society. "The Strategic Guidelines on Development of Lithuanian Education. The Guidelines for Education. 2003-2012.“ (2002) outlined the priorities, goals and objectives of the Lithuanian education, forecast measures and resources necessary to develop an efficient, sustainable system of education in Lithuania, which is accessible to all and ensures lifelong learning. Developed doctoral studies in educational sciences created prerequisites for the planned renewal and reforms of the educational system. Newly trained education researchers 
represent all the educational institutions and become mediators-leaders initiating changes in education and society.

\section{The Expression of Transformational Leadership in Lithuanian University of Educational Sciences}

The leading role, readership of researchers, scientists in the field of education in transformation times can be shown via some personal examples. An educational scientist - leader - is a responsible, creative professional of pedagogy, who is focussed on sustainability principles and lifelong learning and whose activity is based on solid value-based foundation. J. Laužikas is one of such professionals. This was a scientist, who worked in the university, insistently and publicly concentrated own attention and that of communities on the quality of education. During the soviet period this teacher taught the history of Western European pedagogy and supervised students' scientific works in VSPI. The essence of educational interaction of Professor J. Laužikas and his students has been to implement lifelong learning, to ensure the quality of education and sustainability of progress. The Professor made it possible for three gifted graduates (M. Karčiauskienè, A. Grabauskiené, J. Vaitkevičius) from the Department of Pedagogy were sent to post-graduate studies to the then Leningrad. During the post-graduate studies close links with other post-graduate students V. Rajeckas and B. Bitinas were established. In such a way scientific activities of professor J. Laužikas contributed to development of young nurturers of democratic pedagogy.

Having acquired experience, A. Grabauskienè, B. Bitinas, V. Rajeckas and J. Vaitkevičius later became heads of departments. They were concerned about teacher training and sought constructive changes. Their personalities had influence on others while creating future visions. After earning their degree of habilitated doctor, B. Bitinas, M. Karčiauskienè, J. Vaitkevičius and V. Rajeckas created conditions for strong expression of leadership in the academic community, pursued higher teaching/learning quality and were highly committed to implementation of the mission of education. It is obvious that charismatic features were characteristic of mature education researchers. Such features have impact on the surrounding people and create significant and positive changes, which turn ordinary employees into transformational leaders. Leaders play the main role accelerating changes but in educational sciences the followers of transformational leadership, i.e. doctoral students, and their supervisors are inseparable. Vilnius State Pedagogical Institute started a new period in development on 20 May 1992, when the Supreme Council of the Republic of Lithuania granted the status of the university to the Institute. After 1993, when training of research personnel was reformed, many students successfully defended their doctoral dissertations in educational sciences at VPU (Defenders: E. Trečiokienè, L. Rupšienè, J. Vaičiūnaitè, T. Tamošiūnas, 
L. Lukošiūnienè, D. Dvarionas - scientific supervisor Prof. B. Bitinas; A. Rauckienè, R. Vaivada, Z. Žebrauskienè, L. Railienè, M. Gaigalienè, V. Indrašienè, A. Šventickas - scientific supervisor Prof. V. Rajeckas; V. Lamanauskas, V. Grincevičienė, R. Makarskaitė, J. Armonienė, P. Kuprys, R. Jautakaite, R. Malinauskas - scientific supervisor Prof. J. Vaitkevičius; G. Šmitienè, R. Pocevičienè - scientific supervisor Assoc. Prof. A. Grabauskienė). It has to be mentioned that over the first decade of the independence the family of habilitated doctors (in educational science) significantly increased (E. Adaškevičienè, A. Ažubalis, Z. Bajoriūnas, J. Dailidienè, J. Galvydis, A. Katinienè, R. Laužackas, K. Pukelis, J. Skernevičius, L. Šiaučiukènienė and J. Uzdila earned their degree). The development of competences of education researchers showed that the majority of researchers are elderly people. Understanding such leadership of education researchers, it is expected that "this will enable to ensure application of research results in daily practice in the field, will encourage the dialogue between researchers and practitioners, will activate provision and receiving of feedback, will establish possibilities of conducting new and high level research in educational science” (Teresevičienè, 2012, p. 56).

It is obvious making reference to the previously described second period of the growth of education researchers (1993-2003), when the second generation of followers of education researchers-leaders got matured. These were researchers, who earned their degree of habilitated doctor in the second decade of the independence and actively worked in the university. In the context of transformational leadership, education researchers $M$. Barkauskaite, R. Vasiliauskas, A. Raslanas and E. Martišauskienè are related to an exceptional form of influence. They are distinguished by personal features, which inspire doctoral students and motivate them for intellectual growth. Transformational leaders encourage followers to do more than it is usually expected from them (Northouse, 2009, p. 151-152). The abovementioned education researchers became examples for their followers, who understand strengths of doctoral students, inspire them and encourage to assume more responsibility. Habilitated doctors in educational sciences mobilised their potential strengthening positions in the research field of educational sciences (social sciences) and were concerned about the quality of dissertations in educational sciences. Researchers became the figures of authorities to the followers inspiring and motivating the latter for improvement. In the second period the culture of transformational leadership of education researchers was obviously and consistently developed in the university.

Later transformational leadership acquired forms of shared leadership. Shared leadership starts spreading in the community of the university. This leadership is not aimed at formal leaders only - it embraces actions of various people working in an organisation. 
This means that developing shared leadership, all the community members including teachers, administrative staff and students can be regarded as leaders. Such leadership is perceived not as a role of a single individual but also as an ability and capability to take on the role of a leader when necessary. Shared leadership can take a form of an activity, which is shared or implemented by any member of an organisation (Harris et al., 2010). Sharing of leadership in a higher education institution is one of the ways, which help to increase efficiency, to strengthen management and to improve outcomes of research and studies. Thus, shared leadership of education researchers is relevant seeking improvement of the quality of performance of an educational school. This leadership helps to avoid domination of one individual over other people. Developing shared leadership, the head of an institution grants more powers to other employees and sometimes delegates function of own performance to them. Sharing leadership a different member of an organisation becomes a leader depending on the situation and on the individual's possession of specific competences or abilities in a particular situation. Such leadership means that members of an organisation are ready to assume leader's work and responsibility. At present the features of shared leadership are obvious in the university and they are visible implementing educational programmes, projects or research as well as training doctoral students. Developing shared leadership of education researchers attempts are made to enhance employees' responsibility, selfconfidence and trust in colleagues, promote cooperation and strengthen motivation for teaching/learning of the whole community.

Analysing the case of Lithuanian University of Educational Sciences it was established that the generation of education researchers who maturated under conditions of transformational and shared leadership are able to freely and fully participate in maturing and developing social sciences.

Having earned their doctor habilitatus or doctor's degrees at Lithuanian University of Educational Sciences, education researchers also spread to other Lithuanian universities. The greatest number of education researchers have continued their research careers at the following universities in Kaunas: rector Prof. K. Miškinis and A. Dumčienè, head of the Pedagogy and Psychology Department, in the Institute of Physical Culture; Kaunas Technological University - Assoc. Professor V. Bajoriene; Vice-rector K. Pukelis, Professor of Department of Education Science, in Kaunas Vytautas Magnus University; Assoc. Prof. G. Klimoviene, head of the Department of Languages in Aleksandras Stulginskis University. Several researchers worked at Klaipeda University: English Philology Department Assoc. Prof. I. Sabaliauskaite, Head of the Educology Department Assoc. Prof. V. Raudys, Assoc. Prof. A. Rauckienè. Several outstanding education researchers develop educology at Šiauliai University; they include professor V. Lamanauskas, L. Rupšienè, and L. Šiaučiukènienè. A large number of researchers remained at Vilnius State Pedagogy Research Institute; there educology 
is fostered by V. Voveris, Z. Tarvydienè, A. Grybauskienè, R. Vasiliauskas, M. Barkauskaitė, R. Matlašaitienė, V. Bortkevičienè, R. Vaivada, Z. Žebrauskiené, A. Šventickas and other researchers.

It is worth to give a short overview of scientific schools established by some prominent education researchers of Lithuanian University of Educational Science, which nurtured many researchers, who became leaders in research and development of educational sciences as themselves so via their $\mathrm{PhD}$ students.

During the analysed period issues of educational sciences go beyond the field of traditional pedagogy. The research problems expanded to such "spheres as civic society, virtual and information networks, business, politics, community, social groups of various interests” (Teresevičienè, 2012, p. 55). At present the quality problems, competence development and change have become relevant as well. The doctoral dissertations of the last decade have been of diverse themes, working researchers and lecturers have their scientific research areas and involve their doctoral students into them (Teresevičienè, 2012, p. 57). However, at the same time "scientific research on teacher education, systematic nature of education research seeking to coordinate systemic changes in society, embracing all the main problems, individuals from all the social layers and developmental groups" (Barkauskaite, 2008, p. 16) are insufficient. It is critical (Gore, 2017) to reconcile differences within educational research if we are to ensure the strength of the field and support the next generation of researchers to make a more profound impact on schooling and society.

The discussed periods illustrate the tendencies observed in the growth and leadership of education researchers at Lithuanian University of Educational Sciences. The first period (1983-1992) is related to the preservation of unique and significant legacy of pedagogy and consolidation of the pedagogy science at the university. At that time this institution was engaged not only in the preparation of students for their doctor's degree but also in the recognition (nostrification) of formerly awarded academic degrees. Thus, statistical data evidence an increase both in the number and maturity of education researchers. The second period (19932003) shows a minor but almost stabile decrease in the number of students seeking the doctor's degree at the university. At the same time the growth of academic personnel becomes evident - having earned their doctor's diplomas, researchers write their doctor habilitatus degree works or earn their pedagogical titles of professor. The singled out periods of education researchers' growth illustrate a stable condition of the educational sciences within the research area of social sciences at the university. Training of doctoral students and professional growth of colleagues were in hands of prominent educators - leaders. Taking into account the research field of educational sciences (social sciences), it can be stated that the culture of transformational and shared leadership has formed in the universities over a long period of time. The significance of Lithuanian University of Educational Sciences (earlier - Vilnius Pedagogical University), as an important institution of 
education researcher training, has been revealed. This is a higher education establishment, which differed from the other Lithuanian research institutions because research on school pedagogy was carried out there. The growth of the number of education researchers was significant in the university - in the period of 1993-2004 208 diplomas of doctor's degree in educational sciences and 31 certificates of the pedagogical title of the professor were issued. The education researchers, who were granted diplomas of habilitated doctors and doctors in this university spread to other Lithuanian universities. The focus is (Lan, 2020) to enhance the disciplinary independence of educology and regard it as the foundational project for the development of contemporary educology.

The distribution of education researchers - leaders in Lithuanian universities evidences real possibilities of not only competent representation of the research field of educational sciences (social sciences) but also of suggesting changes and practical solving challenges imposed on the school or education in general.

\section{Conclusions}

At the end of the twentieth the educational sciences underwent significant qualitative changes. The term "pedagogy" was replaced by the term "educational sciences" (educology). The conception was established about educational sciences as an integrated science that investigates education and self-education of an individual all his/her life both from the perspective of direct education process and from that of education as a complex phenomenon with educational systems realising it. In the beginning of the 21st century the educational sciences have acquired aspects of fundamentality and its essential methodological characteristics have been formulated.

The maturity of the educational sciences as a result of the quality of pedagogy science highlighted the growth of education researchers in Lithuanian universities. Vilnius State University (VSU, currently VU), Vilnius State Pedagogical Institute (VSPI, currently LEU), Šiauliai Pedagogical Institute (ŠPI, currently ŠU) became the first centres of gravity for the science of education. Training of education researchers in separate universities and their consortiums over a quarter of a century is linked with protection of heritage relevant to pedagogy, consolidation of position of the science of pedagogy and stable training of doctoral students.

The majority of doctoral dissertations were defended in all the Lithuanian universities implementing doctoral studies in educational sciences in the period of 2000-2002. Having evaluated the number of defended dissertations the leadership of certain universities is revealed. Next to such universities as Vilnius University (VU), Vytautas Magnus University (VMU), Klaipeda University (KU), Kaunas University of Technology (KUT), Šiauliai University (ŠU), Lithuanian University of Educational Sciences (LEU) played a significant role in training of education 
researchers. From 1993 to 2004 Lithuanian University of Educational Sciences (LEU) issued one third of the doctor's diplomas in educational science.

The distinguished periods illustrate the developmental tendencies of the science of pedagogy in Lithuanian universities, the turnover of education researchers and potential opportunities for expression and development of leadership. The period of 1990-2004 was marked by well-defined leadership of education researchers in universities. Education researchers, who earned their degrees of doctor habilitatus and doctors in Lithuanian Universities of Educational Sciences (earlier - Vilnius Pedagogical University) spread in other Lithuanian universities. The broad geography of researchers in pedagogy and educational science, who were granted the doctor's diplomas in Lithuanian Universities of Educational Sciences (earlier - Vilnius Pedagogical University) evidence the manifestations of transformational leadership. Having acquired the doctor's diplomas, the researchers leaders have been working in a targeted way towards habilitation degrees and professor's pedagogical titles. Education researchers in Lithuanian universities have access to real possibilities of competent representation of the research field of educational sciences (social sciences) but also of solving challenges imposed on the school or education in general.

\section{References}

Adomaitienė, J., Zubrickienė, I. (2012). Optimalios andragoginès sąveikos modeliavimas sinergetinis pagrindimas, Andragogika: mokslo darbai, No. 1 (3).

Anderson, K. D. (2008). Transformational teacher leadership: Decentring the search for transformational leadership. International Journal of Management in Education, No. 2(2).

Barkauskaite, M. (2008). Pedagogų rengimas: tradicijos ir kaita. Pedagogika: mokslo darbai, vol. 79.

Barkauskaitè, M., Martišauskienè, E., Česnavičienè, J. (2006). Edukologiniai tyrimai ir dabarties iššūkiu kaita. Profesinis rengimas: tyrimai ir realijos, No. 11.

Bass, B. M. (2008). The Bass Handbook of Leadership: Theory, Research, \& Managerial Applications (4th ed.). New York, NY: Free Press.

Bujokaitė [Ratkevičienė] M. (2013). Mokytojo lyderystės raiška. Mokytoju ugdymas: mokslo darbai, No. 20 (1), 58-75.

Dobrovolskis, B. (2009). Iš ugdymo mokslo raidos istorijos. Acta Paedagogica Vilnensia, No. 22.

EU Commission. (2001). The Concrete Future Objectives of Education Systems, Report from the EU Commission, January.

Gore, J. M. (2017). Reconciling educational research traditions. The Australian Educational Researcher, No. 44, 357-372.

Jackūnas, Ž. (2006). Lietuvos švietimo kaitos linkmès. Vilnius, Institute of Culture, Philosophy and Arts.

Jucevičienè, P. (1997). Ugdymo mokslo raida: nuo pedagogikos iki šiuolaikinès edukologijos. Kaunas, Technologija.

Karčiauskienė, M., Vaitkevičius, J., Bitinas, B., Rajeckas, V. (1993). Ar esama Lietuvoje pedagogikos mokslo? Tiesa, 19 March. 
Kelley, J. D. (2011). Teacher's and Teacher Leaders' Perceptions of the Formal Role of Teacher Leadership. Dissertation, Georgia State University.

Lan, Ye. (2020). Life-Practice Educology: A Contemporary Chinese Theory of Education. Brill.

Laurutis, V., Gumuliauskienė A. (2003). Edukologijos mokslas ir pedagogų rengimo kaita Šiauliu universitete. Akademine edukologija, No. 1.

Leithwood, K., Jantzi, D. (1999). The Effects Of Transformational Leadership On Organizational Conditions And Student Engagement With School. Paper presented at the Annual Meeting of the American Educational Research Association (Montreal, Quebec, Canada, April.

Leithwood, K., Jantzi, D. (2006). Transformational School Leadership for Large-Scale Reform: Effects on Students, Teachers, and Their Classroom Practices, School Effectiveness and School Improvement, No. 17, 201-227.

Leithwood, K., Jantzi, D. (1990). Transformational leadership: How principals can help reform school cultures. School Effectiveness and School Improvement, No. 7(4).

Lietuvos švietimo plètotès strateginès nuostatos. (2002). Švietimo gairès. 2003-2012 metai. AB Spauda.

Lithuanian Council of Research. (n.d.). Lietuvos mokslo potencialas. The List of Lithuanian Researchers Registered According to the Issued Diplomas of Doctors of Science.

MacBeath, J., Myers, K. (1999). Effective School Leaders. London: Pearson.

Martinez, MC. (2004). Teachers Working Together for School Success. Thousand Oaks: Corwin Press.

Maslow, A. H. (1954). Motivation and Personality. Oxford, England: Harpers.

Mialeret, G. (1985). Introduction to the Educational Science, UNESCO.

Navickaitè, J., Janiūnaitè, B. (2012). Barriers of school principal's transformational leadership in change process: case study of Lithuanian schools. Socialiniai mokslai, No. 3(77).

Northouse, P. G. (2009). Lyderystè: teorija ir praktika. Kaunas, Poligrafija ir informatika.

Pukelis, K. (1997). Pedagogikos mokslo keliu: profesoriaus Vlado Rajecko buvusiu doktorantu moksliniu straipsniu rinkinys. Kaunas, Versmè.

Rajeckas, V. (1999). Pedagogika - ugdymo mokslas ir menas. Vilnius, Vilnius Pedagogical University.

Rekomendacijos. (2008). Tarpuniversitetinès edukologijos doktorantūros sukūrimas. Profesinis rengimas: tyrimai ir realijos, 181-182.

Rupšienè, L., Skarbalienè, A. (2010). The Characteristics of Teacher Leadership. Tiltai: socialiniai mokslai, No. 4, 67-76.

Santos, J.M., Horta, H. (2018). The research agenda setting of higher education researchers. Higher Education, No. 76, 649-668.

Švietimas. (2001). Education, A360, Vilnius, The Department of Statistics under the Government of the Republic of Lithuania.

Teresevičienè, M. (2012). Tyrimų erdvès išplètimas ugdant edukologijos mokslininkus. Pedagogika: mokslo darbai, No. 108.

Vaitkevičius, J. (1997). Pedagogikos mokslas Lietuvoje 1956-1996 m. (apgintų disertacijų apžvalga). Educational Reform and Teacher Training: proceedings of the 4th international scientific conference, Vilnius, VPU.

Vaitkevičius, J. (1992). Pedagoginès minties raida Lietuvoje 1940-1990 m., In Mokslas ir

Voverienè, O. (1995). Pedagogikos mokslo būklè Lietuvoje mokslotyrininko žvilgsniu (19531992 m.). Mokslas ir Lietuva, 24 May, 7 June. 